\title{
The Relationship between the Levels of Self-efficacy Beliefs of Pre-service Teachers and their Levels of Determining Suitable Taxonomy, Strategy, and Method-technique for Science Objectives ${ }^{\#}$
}

\author{
Gülfem Muşlu Kaygısız*, Neşe Uygun, F. Melike Uçar \\ Department of Primary Education, Hasan Kalyoncu University, Gaziantep, Turkey \\ *Corresponding Author: gulfem.muslu@hku.edu.tr
}

\#Some parts of this research was presented orally as Self-Efficacy in Teaching Science and the Level of Teaching Methods and Techniques of PreService Elementary Teachers in New Perspectives in Science Education, 22-23 March, Florance,Italy.

\section{ABSTRACT}

The purpose of this study was to examine the relationship between the level of pre-service primary school teachers' self-efficacy beliefs in science teaching and their level of determining taxonomy, strategy, and teaching methods-techniques for the curriculum's objectives in primary science education. A total of 101 pre-service teachers who were enrolled in the third and fourth grade of the department of primary school teachers in the 2017-2018 academic year at a private university in Gaziantep, Turkey participated in this study. The level of teacher candidates' self-efficacy beliefs toward science teaching was determined through the "Science Teaching Efficacy Belief Instrument." In addition, teacher candidates' levels and reasons for determining the appropriate taxonomy, strategies, methods, and techniques while teaching the objectives in the science curriculum were examined through "form of determining suitable taxonomy, strategy, and method-techniques for objective." Therefore, qualitative and quantitative data were examined together. This was a correlational study but it was enriched through qualitative data. Results showed that pre-service teachers' self-efficacy beliefs toward science teaching and determination levels of appropriate taxonomy, strategy, and teaching methods-techniques were relatively high. In addition, a statistically weak but positive relationship was found between these two variables. As a result, it is recommended to give more importance to these courses in teacher education of pre-service primary school teachers.

KEY WORDS: primary school teacher education; science teaching; self-efficacy; teaching methods and techniques

\section{INTRODUCTION}

I $\mathrm{n}$ the renewed Turkish science curriculum in 2018, it was proposed to apply methods, techniques, and strategies based on problems, projects, argumentation, cooperation, and research-inquiry (MoNE, 2018). In this regard, more innovative roles and responsibilities have been assigned to teachers. For instance, it is expected from teachers to encourage students to undertake research and guide them through this process by taking the holistic relationship between science, technology, engineering, and math disciplines into consideration and also to create a democratic and student-centered learning environment where students can express themselves, improve their questioning and communication skills and cooperate with their peers so that they can reach an advanced level of thinking, product development, invention, and innovation (MoNE, 2018). For this to happen, it was proposed to apply methods, techniques, and strategies based on problems, projects, argumentation, cooperation, and research-inquiry (MoNE, 2018). Therefore, it is even more important for teachers and prospective teachers to be competent in determining the appropriate methods, techniques, and strategies to be used in creating such learning environments. To have this competence, Yilmaz et al. (2004) stated that teachers should also have high beliefs that they can perform their duties and responsibilities, in addition to having a good education. Y1lmaz and Çimen (2008) stated that it is not in itself enough to have knowledge and skills regarding teaching formation, professional field, and general knowledge but one should also have belief in their selfefficacy to be a competent teacher. For this reason, it is thought that pre-service teachers should graduate being fully equipped and with enough belief in their efficacy.

Self-efficacy belief is defined in Bandura's (1986) social learning theory as "judgments of people regarding their capacities of coordinating and implementing activities to achieve specific performance types" (p. 391). The term, "teacher self-efficacy" is defined by Aston (1984) as the beliefs of teachers in their talents of influencing the performances of students and fulfilling their duties during the teaching process. According to Gibson and Dembo (1984), teacher self-efficacy plays an important role in explaining individual differences that cause the given education to have different impacts. It has also been indicated that teacher self-efficacy belief is 
influential in creating the learning environment that would be formed to advance the academic and cognitive skills of students (Bandura, 1997). In addition to that, it was also stated that teachers' beliefs about their instructional competencies were effective in forming activities in their classroom (Çolak et al., 2017). For instance, it has been seen that teachers and pre-service teachers with more self-efficacy belief used various teaching strategies (Riggs and Enochs, 1990; Koray, 2003). Likewise, it has been revealed that these teachers tend to use student-centered strategies and make research to use these methods and strategies more efficiently while those with less self-efficacy belief tend to teach with a teacher-centered strategy and by reading the textbooks (Henson, 2001; Plourde, 2001).

Pajares (1996) stated that self-efficacy belief displays a structure that is specific for more special fields. In other words, self-efficacy belief can be more meaningful when thought as field-specific. Therefore, examining teacher self-efficacy belief within the scope of teaching different disciplines is important in terms of obtaining more accurate results. Hence, self-efficacy belief toward science teaching can be defined as the judgments and beliefs regarding the individual talents of a person aimed at following an efficient and effective path during science teaching and therefore helping the education of the students by increasing their success (Akbaş and Çelikkaleli, 2006; Özkan et al., 2004).

After the year 2012, elementary school students in Turkey started to take science courses from the third-grade level (students aged from 8 years old). In the third and fourth grades, this course is conducted by primary school teachers, while from the fifth grade to eighth grade, they are conducted by science teachers. Therefore, it is significantly important for pre-service teachers to have high levels of self-efficacy regarding that they can teach science efficiently, to be fully equipped regarding science teaching, and to endear and teach science to the students who will encounter science for the $1^{\text {st }}$ time. However, studies have shown that primary school teachers lack in science content knowledge and using contemporary teaching methods in science (Sönmez, 2007; Yangın and Dindar, 2007; Taşkaya and Sürmeli, 2014).

However, as mentioned above, for the students to acquire the knowledge and skills emphasized in the science curriculum, primary school teachers who are fully equipped in this field and are aware of their self-efficacy are needed. At the same time, due to the fact that most of the studies in the related literature are conducted on branch teachers such as science, mathematics, there is a need for studies that will help primary school teachers to advance themselves in this field. For this reason, both determining the methods and techniques that primary school teachers will use during teaching, suitable to the subject, objectives, and grade and the revealing of the relationship between this level and self-efficacy beliefs of pre-service teachers regarding science teaching is thought to be an important step to meet the current need.
Therefore, this study aimed to examine the relationship between the level of pre-service primary school teachers' self-efficacy beliefs in science teaching and their level of determining taxonomy, strategy, and teaching methodstechniques suitable for the curriculum's objective in primary science education. In accordance with this purpose, this study sought to answer the following questions:

1. What is the level of self-efficacy beliefs of pre-service primary school teachers toward science teaching and what are the appropriate taxonomy, strategy, and methodtechniques determination levels for science objectives? Is there a significant difference in these variables according to grade level?

a. What are the self-efficacy levels of pre-service teachers regarding objective expectation subdimension? Is there a significant difference in this variable regarding class levels?

b. What are the self-efficacy beliefs of pre-service teachers regarding self-efficacy belief subdimension? Is there a significant difference in this variable regarding class levels?

c. What are the levels of pre-service teachers when it comes to classifying science objectives, according to bloom's taxonomy? Is there a significant difference in this variable regarding class levels?

d. What are the levels of pre-service teachers when it comes to determining a suitable strategy? Is there a significant difference in this variable regarding class levels?

e. On which levels are the pre-service teachers in when it comes to determining suitable method-techniques in line with objectives? Is there a significant difference in this variable regarding class levels?

2. What is the relationship between pre-service primary school teachers' self-efficacy belief levels toward science teaching and their level of using appropriate taxonomy, methods, techniques, and strategies?

3. What are the reasons for pre-service primary school teachers to choose the objectives they have determined for their science teaching practices? Are there any differences in these choices by grade level?

4. What are the reasons for pre-service primary school teachers to choose the methods, techniques, and strategies they have determined for their science teaching practices? Are there any differences in these choices by grade level?

\section{METHODS}

\section{Research Design}

For this study to examine the relationship between the level of pre-service primary school teachers' self-efficacy beliefs in science teaching and their level of determining taxonomy, strategy, and teaching methods-techniques suitable for the curriculum's objective in primary science education, a correlational research method was used. "Correlational 
research is conducted to determine the relationship between two and more variables and to get clues regarding cause and effect" (Büyüköztürk et al., 2016. p. 15). With this in mind, this study aimed to analyze the reasons why pre-service teachers choose the objectives they chose for science teaching and the techniques and strategies that they determined according to these objectives. Therefore, the study has been enriched by referring to qualitative data to elaborate on the obtained quantitative data.

\section{Study Group}

This study was conducted with the 2017-2018 academic year junior ( $3^{\text {rd }}$ grades) and senior ( $4^{\text {th }}$ grades $)$ pre-service teachers of a private university in Gaziantep. One hundred and twentytwo pre-service teachers participated in the study; however, only 103 fully completed the two scales of the study. After the pre-analysis, data of two participants were also taken out of the study because these participants were considered as outliers. As a result, the study group consists of 101 pre-service teachers including 32 seniors and 69 juniors. The reason why participants were chosen from juniors and seniors is that all of these students have taken the course: "Principles and methods of teaching, science teaching I" and that seniors have taken the course: "Science teaching II." Within the scope of these courses, preservice teachers theoretically have received training on science objectives that are in the primary school curriculum, classifying these objectives in accordance with Bloom's Taxonomy, and on methods, techniques, and strategies that are used in science teaching. In addition to that senior year, pre-service teachers have also completed their applied courses. The participants were informed about the study and they were ensured that their names and the information get from them would be kept confidential. In addition, their oral approvals were received.

\section{Data Collection Tools}

\section{Science teaching efficacy belief instrument (STEBI)}

The scale that was used in this study to evaluate the selfefficacy beliefs of pre-service teachers in science teaching was the "STEBI" which was developed by Riggs and Enochs (1990) and adapted into Turkish by Hazır-Bıkmaz (2004). The scale consists of 20 items using a 5-point Likert scale and consisting of two dimensions: One being self-efficacy belief in science teaching $(\mathrm{n}=13, \alpha=0.78)$ and the other being objective expectation in science teaching $(\mathrm{n}=7, \alpha=0.60)$. The reliability coefficient for the scale was reported to be 0.71 (Hazır-Bıkmaz, 2004). The reliability coefficient of the scale in the scope of this research was calculated at $\alpha=0.70$ for self-efficacy belief in science teaching, $\alpha=0.63$ for objective expectation in science teaching, and $\alpha=0.72$ for the whole scale.

\section{Form of determining objective-oriented taxonomy, strategy, and method-techniques of pre-service primary school teachers (TSMTDF)}

The form used in this study was developed by researchers to evaluate the levels of pre-service teachers when it comes to determining suitable objective-oriented taxonomy, strategy, and method-techniques. The content and logistic suitability of the questions in the form was controlled by two science educators and the linguistic suitability was controlled by a linguist. This form contains the following open-ended articles related to pre-service teachers' science teaching.

1. Choose at least two objectives among the science teaching curriculum for primary school third and fourth grades

2. Classify the objectives you chose according to Bloom Taxonomy

3. Determine the suitable teaching strategy regarding the objective you chose

4. Determine suitable teaching methods and techniques for the objective you chose

5. Explain why you chose that objective

6. Explain why you chose those methods, techniques, and strategies.

Researchers of this study developed a rubric related to these items to obtain numeric data regarding how pre-service teachers associate the methods and techniques they learned with science objectives. In this rubric, the levels of preservice teachers when it comes to choosing suitable teaching strategies, methods, and techniques (SMT) and classifying the objectives they chose according to Bloom's Taxonomy have been scored. During the scoring process, 2 points were given for true answers, 1 for partly true answers, and 0 for wrong answers. These points were calculated for each of the preservice teachers. The maximum score the pre-service teachers could get was 6 and the minimum was 0 . This form was also used as a data obtaining device to examine in detail, why preservice teachers chose the objective and the teaching methods, techniques, and strategies that they chose.

The scores that pre-service teachers got from this form were compared to their Science Teaching I course passing grades to increase the reliability of the form. For this reason, Pearson Correlation coefficients were calculated between the scores pre-service teachers got from this form and their passing grades. The results showed that there was a weak but positive and significant relationship between these two scores $(r=0.242, \rho<0.05)$. Therefore, it has been revealed that the form used served its purpose.

\section{Data Collection Procedure}

"Form of determining objective-oriented TSMTDF' and "STEBI" were administered during the spring semester of the 2017-2018 academic year. The pre-service teachers first filled out the STEBI in $30 \mathrm{~min}$ in class. The participants were given a week to fill out TSMTDF at home. The participants were also notified about the filling out of the form and asked to choose the science objectives from the Science Course Curriculum (MoNE, 2018).

\section{Data Analysis}

Quantitative data obtained from this study were analyzed in two ways: Descriptive and inferential. To determine the levels of pre-service teachers when it came to classifying science objectives according to bloom taxonomy and their levels of using objective-oriented suitable methods and techniques, 
descriptive statistics were used and mean and standard deviation values were calculated for these variables. As a way of inferential statistics, the simple correlation was used by calculating Pearson Correlation Coefficient to examine the relationship between pre-service teachers' level of self-efficacy beliefs and their level of determining suitable taxonomy, strategy, teaching methods, and techniques. In addition to this, using independent samples t-test, it was tested whether the variables of this study differ according to grade level.

Qualitative data in this study were obtained from the answers given to open-ended questions. Content analysis was conducted using open-coding. To ensure the reliability of the analysis, the two field experts created codes from different data. To calculate the consistency between these codes, agreement percentage formula (Reliability $=$ Agreement/[Agreement + Disagreement] $\times 100)$ of Patton (2002) was used. The first agreement was calculated as 0.90 . The second agreement percentage of the codes who disagreed was calculated again after the researchers examined the data. The final agreement percentage has been found to be 0.96 . After that, different themes were created from the consensus codes using inductive analysis for each question to explain the obtained data on a global level. The created codes are represented in the results section in tables with their frequencies and percentages. In addition, there were direct quotations to illustrate the codes in the table to increase reliability.

\section{FINDINGS}

In this section, the findings obtained from qualitative and quantitative data are presented in line with the research questions.

\section{Findings for the $1^{\text {st }}$ Research Question}

This section includes the findings regarding pre-service teachers' self-efficacy beliefs toward science teaching and determination levels of appropriate taxonomy, strategy, teaching methods-techniques for objectives.

Table 1 shows the results of descriptive statistics of STEBI, and form of determining objective-oriented TSMTDF.

As Table 1 demonstrates, the level of self-efficacy beliefs of pre-service teachers toward science $(X=70.50)$ and the level of determining appropriate taxonomy, method, technique, and strategy $(X=3.70)$ was relatively high. When the TSMTDF scores of pre-service teachers were compared, it was seen that their level of determining the appropriate taxonomy was low $(X=0.51)$ while determining strategy $(X=1.58)$ and methodtechnique $(X=1.60)$ were similar and high.

In addition, an independent sample t-test was performed to see the difference between the different grade levels in determining appropriate taxonomy, method, technique, strategy, and self-efficacy beliefs of pre-service teachers. The results of the analysis are given below in Table 2.

Table 2 demonstrates that efficacy belief $(t=-0.10, \rho>0.05)$, outcome expectancy $(t=0.93, \rho>0.05)$, and self-efficacy belief $(t=0.44, \rho>0.05)$ did not have a significant difference based on the grade levels. In addition, it was seen that both the level of total objective-oriented taxonomy, instructional method, technique, and strategy determining $(\mathrm{t}=0.27, \rho>0.05)$, and the level of strategy determining $(t=1.61, \rho>0.05)$ did not differ according to grade level. Moreover, seniors had higher scores than the juniors in determining taxonomy $(\mathrm{t}=-2.58, \rho<0.05)$ and determining method-technique $(\mathrm{t}=2.13, \rho<0.05)$.

\section{Findings for the $2^{\text {nd }}$ Research Question}

This section includes the findings regarding the difference between the levels of pre-service teachers' self-efficacy beliefs toward science teaching and determining appropriate objectiveoriented taxonomy, strategy, and teaching methods-techniques.

Pearson product-moment correlation analysis was used to investigate the correlation between pre-service teachers' self-efficacy beliefs toward science teaching and determining appropriate objective-oriented taxonomy, strategy, teaching methods-techniques, and Pearson correlation coefficient was calculated. Table 3 presents the related results.

Table 3 reveals the results of Pearson product-moment correlation analysis indicating that there was a statistically significant and a positive correlation between pre-service teachers' self-efficacy beliefs toward science teaching and determining appropriate objective-oriented taxonomy, strategy, and teaching methods-techniques $(r=0.206 ; \rho<0.05)$. Although the correlation between the two variables was significant, it was low according to Cohen (1988).

\section{Findings for the $3^{\text {th }}$ Research Question}

The findings regarding the reasons why pre-service teachers chose those objectives that they determined for science teaching and whether these choices were different depending on the class levels are demonstrated in this section. By asking the question: "Why did you choose that objective?" To preservice teachers, it was aimed to determine which criteria that they prioritized. The answers that pre-service teachers gave to that question were examined using codes and themes related to these codes (Table 4). Because of the fact that pre-service teachers gave opinions regarding different codes, the number of codes was more than those of pre-service teachers.

As shown in Table 4, the junior pre-service teachers mostly answered the research question with the themes such as the

\begin{tabular}{lccccc}
\hline \multicolumn{6}{l}{ Table 1: Descriptive statistics of STEBI and TSMTDF } \\
\hline Variables & $\mathbf{n}$ & Min & Max & $\mathbf{X}$ & SS \\
\hline Self-efficacy belief in science teaching & 101 & 46 & 88 & 70.50 & 6.97 \\
Efficacy belief & 101 & 34 & 56 & 45.45 & 4.93 \\
Outcome expectancy & 101 & 12 & 35 & 25.05 & 3.83 \\
Total TSMTDF score & 101 & 0 & 6 & 3.70 & 1.53 \\
Determining taxonomy & 101 & 0 & 2 & 0.51 & 0.78 \\
Determining strategy & 101 & 0 & 2 & 1.58 & 0.68 \\
Determining method-technique & 101 & 0 & 2 & 1.60 & 0.63 \\
\hline
\end{tabular}

STEBI: Science teaching efficacy belief instrument, TSMTDF: Taxonomy, strategy, and method-techniques determination form 


\begin{tabular}{|c|c|c|c|c|c|c|}
\hline Dependent variable & Independent variable groups & $\mathbf{n}$ & $x$ & SS & $t$ & $\rho$ \\
\hline \multirow[t]{2}{*}{ Self-efficacy belief in Science teaching } & Junior & 69 & 70.71 & 6.83 & 0.44 & 0.66 \\
\hline & Senior & 32 & 70.05 & 7.38 & & \\
\hline \multirow[t]{2}{*}{ Efficacy belief } & Junior & 69 & 45.42 & 4.93 & -0.10 & 0.92 \\
\hline & Senior & 32 & 45.52 & 5.01 & & \\
\hline \multirow[t]{2}{*}{ Outcome expectancy } & Senior & 69 & 25.30 & 3.82 & 0.93 & 0.35 \\
\hline & Senior & 32 & 24.53 & 3.88 & & \\
\hline \multirow[t]{2}{*}{ Total TSMTDF score } & Junior & 69 & 3.72 & 1.52 & 0.27 & 0.79 \\
\hline & Senior & 32 & 3.63 & 1.59 & & \\
\hline \multirow[t]{2}{*}{ Determining taxonomy } & Junior & 69 & 0.38 & 0.78 & -2.58 & $0.01 *$ \\
\hline & Senior & 32 & 0.80 & 0.71 & & \\
\hline \multirow[t]{2}{*}{ Determining strategy } & Junior & 69 & 1.65 & 0.68 & 1.61 & 0.11 \\
\hline & Senior & 32 & 1.42 & 0.65 & & \\
\hline \multirow[t]{2}{*}{ Determining method-technique } & Junior & 69 & 1.41 & 0.62 & 2.13 & $0.04 *$ \\
\hline & Senior & 32 & 1.70 & 0.60 & & \\
\hline
\end{tabular}

$* \rho<0.05$. TSMTDF: Taxonomy, strategy, and method-techniques determination form

Table 3: Results of Pearson product-moment correlation analysis of the scores of STEBI and TSMTDF

\begin{tabular}{lcccc}
\hline Variable & $\mathbf{n}$ & $\mathbf{r}$ & $\boldsymbol{\rho}$ \\
\hline Science teaching self-efficacy belief * total & 101 & 0.206 & $0.038^{*}$ \\
TSMTDF score & & & \\
\hline$* \rho<0.05 . \quad$ STEBI: Science teaching & $\begin{array}{c}\text { efficacy } \\
\text { TSMTDF: Taxonomy, strategy, and method-techniques determination form }\end{array}$
\end{tabular}

teaching process, professional knowledge, professional quality, and learning process. The senior pre-service teachers mostly answered with the themes such as learning process, teaching process, professional knowledge, and professional quality.

Table 4 shows that the most chosen reason in choosing objectives regarding the teaching process was the fact that "teaching is easy." Therefore, pre-service teachers prioritized the objectives that they think they can teach easily. It can also be seen that senior year pre-service teachers included this code the most as a reason for choosing objectives. Below, there is a direct quotation from one of the participants. The first written number in quotations shows the grade level and the other shows the number given to the participant "...Teaching is easy and it is a subject that I prepared fondly." (4.2)

Again, within the scope of the teaching process theme, it was also seen that pre-service teachers preferred those objectives that they could support with materials while teaching. Junior year students expressed their opinions more when it came to supporting the teaching process with materials. Junior year pre-service teachers considered themselves efficient when it came to the concretization of the subjects and developing materials that were suitable for the objective. The following are quotations to illustrate this situation.

"I chose this objective because I thought that I could prepare an easier and more beneficial material for this objective." (3.10)

"...I think I can teach better with sufficient material and presentation." (3.14)
In addition to this, the pre-service teacher prioritized the objectives that the students would be more active about and that they think can associate it with daily life. Pre-service teachers also choose the objectives with the aim of raising conscious individuals.

"By emphasizing the differences between natural and artificial environments, they will get an idea of how the living creatures around them were formed. They will learn how to act around the living creatures that they encounter or see, learn how they harm or benefit the environment and us and, know what they do then they will act accordingly." (3.8)

"I chose this objective because I wanted the students to be more conscious." (4.21)

Besides, while senior year pre-service teachers included codes aimed at exemplifying, using their scientific process skills, easily using methods and techniques that they would use while teaching the objective that they chose; juniors did not express their opinions on these subjects.

Finally, a junior year pre-service teacher stated that s/he chose the objective because $\mathrm{s} /$ he thought that it could be designed into an activity suitable for the class level. S/he was confident about organizing an activity suitable for the aimed age group.

The codes in the professional knowledge theme showed that whether the professional knowledge of pre-service teachers sufficient or not was a factor while deciding on the objective. The participating pre-service teachers stated that they chose the objectives because they thought that they had sufficient professional knowledge. Being sufficient in professional knowledge was an important factor in choosing an objective for almost half of the pre-service teachers while some of the pre-service teachers stated that their professional knowledge was not sufficient enough and that they chose the objectives to eliminate their deficiencies.

"....The reason why I chose this objective is that I was not able to understand after which movements that night-day and 
Table 4: Findings regarding the data obtained from the question: "Why did you choose this objective?"

\begin{tabular}{|c|c|c|c|c|c|}
\hline \multirow[t]{2}{*}{ Themes } & \multirow[t]{2}{*}{ Codes } & \multicolumn{2}{|c|}{ Junior } & \multicolumn{2}{|c|}{ Senior } \\
\hline & & $\mathbf{F}$ & $\%$ & $\mathbf{F}$ & $\%$ \\
\hline \multirow[t]{11}{*}{ Teaching process } & Teaching is easy & 23 & 33.3 & 20 & 62.5 \\
\hline & Supporting teaching with materials & 14 & 20.2 & 2 & 6.2 \\
\hline & Relating teaching to daily life & 8 & 11.6 & 6 & 18.7 \\
\hline & Making use of active learning & 4 & 5.8 & 2 & 6.2 \\
\hline & Changing behaviors & 3 & 4.3 & 4 & 12.4 \\
\hline & Interdisciplinary teaching & 2 & 2.9 & 2 & 6.2 \\
\hline & Contemporary topics & 1 & 1.44 & 1 & 3.1 \\
\hline & Using scientific process skills & 0 & 0 & 5 & 15.6 \\
\hline & Applying methods and techniques easily & 0 & 0 & 4 & 12.4 \\
\hline & Multi-sampling & 0 & 0 & 2 & 6.2 \\
\hline & Compliance with class level & 1 & 1.44 & 0 & 0 \\
\hline \multirow[t]{2}{*}{ Professional knowledge } & To have sufficient professional knowledge & 30 & 43.5 & 15 & 46.8 \\
\hline & Not having enough professional knowledge & 13 & 18.8 & 4 & 12.4 \\
\hline \multirow[t]{4}{*}{ Professional quality } & Having self-confidence & 12 & 17.4 & 2 & 6.2 \\
\hline & Being experienced & 11 & 15.9 & 4 & 12.4 \\
\hline & Eliminating one's own shortcomings & 6 & 8.7 & 4 & 12.4 \\
\hline & Improving oneself in methodological and technical application & 2 & 2.9 & 0 & 0 \\
\hline \multirow[t]{6}{*}{ Learning process } & Pre-service teacher's interest & 6 & 8.7 & 8 & 24.8 \\
\hline & Active participation of students & 2 & 2.9 & 4 & 12.4 \\
\hline & Providing learning with fun & 3 & 4.3 & 4 & 12.4 \\
\hline & Permanent learning & 3 & 4.3 & 3 & 9.3 \\
\hline & Making learning easier & 2 & 2.9 & 2 & 6.2 \\
\hline & Preventing misconceptions & 2 & 2.9 & 0 & 0 \\
\hline
\end{tabular}

Table 5: Findings regarding the data obtained from the question: "Why did you choose this teaching strategy, method, and technique?"

\begin{tabular}{|c|c|c|c|c|c|}
\hline \multirow[t]{2}{*}{ Themes } & \multirow[t]{2}{*}{ Codes } & \multicolumn{2}{|c|}{ Junior } & \multicolumn{2}{|c|}{ Senior } \\
\hline & & $\mathbf{F}$ & $\%$ & $\mathbf{F}$ & $\%$ \\
\hline \multirow[t]{15}{*}{ Teaching process } & Appropriateness of the content of the objectives & 51 & 73.9 & 17 & 53.1 \\
\hline & Permanent learning & 15 & 21.7 & 0 & 0 \\
\hline & Confidence in being able to practice suitable methods and techniques & 8 & 11.6 & 3 & 9.4 \\
\hline & Appropriate for bloom taxonomy & 8 & 11.6 & 1 & 3.1 \\
\hline & Providing research skills & 6 & 8.7 & 3 & 9.4 \\
\hline & Revision & 6 & 8.7 & 2 & 6.2 \\
\hline & Believing that the student can learn easily & 5 & 7.2 & 2 & 6.2 \\
\hline & Concretization & 4 & 5.8 & 0 & 0 \\
\hline & Practicality & 3 & 4.3 & 4 & 12.4 \\
\hline & Guiding for research & 3 & 4.3 & 1 & 3.1 \\
\hline & Appropriate for crowded classes & 3 & 4.3 & 0 & 0 \\
\hline & Practicality & 3 & 4.3 & 0 & 0 \\
\hline & Attractiveness & 2 & 2.9 & 1 & 3.1 \\
\hline & Improving oneself in that particular method and technique & 2 & 2.9 & 0 & 0 \\
\hline & Appropriateness for extracurricular learning & 0 & 0 & 1 & 3.1 \\
\hline \multirow[t]{6}{*}{ Learning process } & Active participation of students & 13 & 18.8 & 18 & 56.2 \\
\hline & Active learning & 10 & 14.5 & 11 & 34.4 \\
\hline & Enjoyable learning & 7 & 10.1 & 5 & 15.6 \\
\hline & Connect with daily life & 4 & 5.8 & 1 & 3.1 \\
\hline & Providing creative thinking skills & 3 & 4.3 & 0 & 0 \\
\hline & Providing critical thinking skills & 2 & 2.9 & 1 & 3.1 \\
\hline \multirow[t]{3}{*}{ Measurement and evaluation } & Detecting prior knowledge & 4 & 5.8 & 2 & 6.2 \\
\hline & Ability to measure & 1 & 1.45 & 1 & 3.1 \\
\hline & Ability to evaluate & 2 & 2.9 & 0 & 0 \\
\hline
\end{tabular}


years formed and I always mixed them up. I don't know this subject and want to learn..." (3.10)

“..I chose this objective because I thought that my professional knowledge is sufficient...” (4.19)

The professional quality theme revealed that senior pre-service teachers expressed a lesser opinion regarding this theme. These pre-service teachers stated that the reason for choosing the objectives was mostly focused on their self-confidence and experience depending on their positive opinions about the objectives. The pre-service teachers felt confident that they would be able to explain the objectives. In addition, some preservice teachers stated that they had experience based on some of the lessons they had taken before. Some of the pre-service teachers saw themselves as experienced in teaching objectives because they did research specifically to teach them. Some of the pre-service teachers described the reason for choosing the gain as a means of eliminating their inadequacies. Another reason was to gain experience in various fields. In addition, a small number of third-grade pre-service teachers stated that they chose the objective to learn the method techniques that they deemed to be inadequate.

"... I have incompetency...., I wanted to have the ability to manage the class on my own...” (3.65)

The codes in the learning process theme indicated that preservice teachers aimed to make students active and tend to choose the objectives accordingly. The pre-service teachers believed that learning became more permanent when students actively participate in their own learning process. See below for an example:

"... I chose this objective because I believe that a course in which students are active participants is more efficient. In this way, learning will be more permanent..." (3.11)

The pre-service teachers also indicated that they choose objectives based on their own interests. Few pre-service teachers stated the reason for choosing the objectives as making learning easy. Furthermore, some of the junior preservice teachers mentioned the reason for eliminating the misconceptions. In other words, they chose the objectives to prevent misconceptions in science courses.

\section{Findings for the $4^{\text {th }}$ Research Question}

This section includes the findings of the fourth research question "What are the reasons for primary school teachers to choose the methods, techniques, and applications for the objectives? Are there any differences between different grade levels?" The answers of the pre-service teachers were analyzed in the light of codes and themes (Table 5).

Table 5 reveals that the most selected reason for determining the instructional strategy, method, and technique (SMT) was "appropriateness of the content of the objectives." That is, most of the pre-service teachers determined SMT based on the objective content. The junior pre-service teachers put emphasis on this option more than the other group. Moreover, only junior pre-service teachers stated that permanent learning would be provided with these SMT. In other words, they thought that discovery learning was permanent learning.

Another factor in determining the methods and techniques was self-confidence in applying these methods and techniques. Furthermore, these pre-service teachers, especially juniors, believed that it was important for SMT to be in line with Bloom's taxonomy. Other factors that affected pre-service teachers' choices were related to the objectives of science teaching such as providing research skills, concretization, and guiding for research/application.

The pre-service teachers also wanted to improve their inadequacies regarding the applications of these methods and techniques by choosing them. Pre-service teachers mentioned this option in the third research question as well. Furthermore, they tended to choose practical SMT. Appropriateness for the crowded classes and revision are mentioned as well.

Finally, a pre-service teacher stated that appropriateness for extracurricular learning was the reason for determining the objectives, making the learning process more efficient. The codes in the learning process theme revealed that facilitating students to be active participants in the lessons and employing a student-centered approach were two of the reasons in determining SMT. They also addressed the role of the science teacher in the classroom. Aside from these, an enjoyable learning environment, making connections with daily life were mentioned as other reasons. Moreover, providing an environment for critical and creative thinking were the two of the factors affecting the determination of SMT.

The codes in the theme of measurement and evaluation showed that the selection of SMT has a role in the assessment as well as the instructional process. Students tend to use alternative assessment methods. Below is an example from a participant about this matter.

"... With the model I prepared for the demonstration technique I selected, I aimed to teach the subject as well as to determine the students' prior knowledge..." (3.37)

\section{DISCUSSION AND CONCLUSION}

In this study, the relationship between pre-service teachers' self-efficacy beliefs toward science teaching and the level of determining appropriate objective-oriented taxonomy, strategy, and teaching methods-techniques was investigated. While doing this, first, the descriptive analysis was performed to analyze these two variables with their subdimensions and the difference between two groups in terms of these two variables was examined.

Accordingly, results revealed that the participating pre-service teachers' self-efficacy beliefs toward science teaching were relatively high. Similar studies (Çorapçıgil et al., 2016; Gökgül, 2013; Y1lmaz, 2014) found that pre-service teachers' self-efficacy beliefs toward science teaching was medium 
level or sufficient; while some studies (Meriç and Ersoy, 2007; Serin and Bayraktar, 2015) revealed that it was high or good. In this study, mean scores ranged between 50 and 85 and concentrated on 70 . This may be caused by the individual differences (early life experiences, learning styles, intelligence types, etc.) as well as the practice teaching courses that some of them have taken and some of them have not taken yet. In their study, Çorapçıgil et al. (2016) found that the main reason for pre-service teachers' feeling insufficient in science teaching was "not having taken enough practice courses." Moreover, several studies (Bayraktar, 2011; Bergman \& Morphew, 2015; Kazempour, 2014; Kazempour and Sadler, 2015; Knaggs and Sondergeld, 2015; Morrell and Carroll, 2003) revealed that science teaching courses have a positive effect on pre-service teachers' self-efficacy beliefs in science teaching. Some other studies (Flores, 2015; Gunning and Mensah, 2011; Hechter, 2011) pointed out that practice teaching courses have a positive effect on pre-service teachers' self-efficacy beliefs in science teaching. In this study, all of the pre-service teachers had taken science teaching I course; some of them (seniors) had taken science teaching II and practice teaching I courses as well. This could be the reason for a high level of self-efficacy. Furthermore, the difference between the self-efficacy levels of the two different grades was examined and no difference was found. These results may be caused by individual differences as well as whether or not the pre-service teachers have taken science teaching I course. Therefore, future studies may investigate the effect of the Science Teaching I course on the self-efficacy level of pre-service teachers.

When the level of determining appropriate objective-oriented taxonomy, strategy, and teaching methods-techniques was examined, it was seen that this level was relatively high. In addition, it was also seen through qualitative data that preservice teachers perceived themselves sufficient in the teaching process. Related literature in this field revealed that primary school teachers and pre-service teachers have difficulty in applying certain methods and techniques and therefore, having self-confidence issues causing them to prefer traditional methods more (Bardak and Karamustafaoğlu, 2006; Taşkaya and Sürmeli, 2014). However, the present study showed that the participants had difficulty in determining taxonomy, they were good at determining strategy and method-technique. As mentioned previously, together with the individual differences, it can be thought that the effect of the courses taken by the pre-service teachers may constitute the difference in the results of this study from the studies in the literature. For this reason, the difference between the levels of determining appropriate objective-oriented taxonomy, strategy, teaching methods-techniques of third graders and fourth graders was examined. Results showed that the pre-service teachers in fourth grade were significantly better at determining taxonomy and method-technique than pre-service teachers in third grade. Consequently, it can be said that science teaching II and practice teaching courses may have constitute of this difference.
When the positive correlation found in this study (between pre-service teachers' self-efficacy beliefs toward science teaching and the level of determining appropriate objectiveoriented taxonomy, strategy, and teaching methods-techniques) interpreted with the related literature, it can be said that this correlation, though weak, indicates that the self-efficacy beliefs of pre-service teachers associate with the method, technique, and materials they are planning to use and thus may affect the quality of their teaching (Klausmeier and Allen, 1978). Similarly, Avc1 (2008) found that the pre-service teachers who had a high level of self-efficacy took on a more studentcentered approach in science teaching rather than a teachercentered one. On the other hand, some studies (Balbağ and Karaer, 2017; Akbaş and Çelikkaleli, 2006; Huyugüzel-Çavaş and Kesercioğlu, 2008) found that even though primary school teachers saw themselves efficient in science teaching, they were less sufficient in their in-class applications. Thus, it could be said that the reason for the weakness of the relationship may be due to the fact that even though the teacher candidates' proficiency especially about determining taxonomy, strategy, and teaching methods were not high enough, they perceived that they were good at science teaching. The qualitative data in this study also revealed that seniors were more realistic and conscious while determining the suitable strategy, methodtechnique compared to third graders. This way, the importance of experience for teacher candidates is emphasized because it is thought that as teacher candidates gain experience, they can make more realistic and effective choices about teaching for their students. Therefore, it is recommended to primary school teaching departments to increase the number of practice courses especially about science teaching, in which primary school teachers perceive themselves as insufficient.

Moreover, when the reasons for selecting objectives were examined, it was seen that the answers of both seniors and juniors were mostly related to the teaching process. In the scope of the teaching process theme, juniors prefer the objectives which they can support with materials. The reason for this is probably because of the Instructional Technology and Materials Design that students had taken along with the other courses. Teacher candidates stated that they prepared their materials considering both of the courses when they explain the reasons why they choose those objectives. In addition, it was also seen that seniors were more focused on the learning process themes than professional knowledge and professional quality themes compared to juniors.

It was also seen that these pre-service teachers choose objectives with the aim of raising conscious individuals through associating the objective with daily life. In particular, the selection of objectives to gain behavior shows that these teacher candidates were more sensitive to these issues. For instance, since students learn the topic of being a conscious consumer in both environmental education and social studies courses, it was believed that pre-service teachers preferred to use these common objectives for the science teaching course as well. The curriculum of the primary school 
education department includes various disciplines. Therefore, interdisciplinary applications may affect the quality of the instruction in that sense. The present study did not include the opinions of the participants on this issue; therefore, this would be an area for future studies.

In addition, the fact that the background knowledge was sufficient or not was seen as another factor in the selection of objectives. Some of the pre-service teachers stated that feeling efficient in the field was effective in determining objectives, while some of them stated that they choose the objectives to help eliminate the things they lack. This indicates that these pre-service teachers made an effort in their own professional development as they were aware of their own knowledge gaps. Practicing pre-service teachers to support their own development can make them more ready for their professional lives. In this regard, it is thought that applied courses at university are important in teacher training.

It was also found that pre-service teachers prefer the SMTs that were practical and more appropriate for their crowded classes. These reasons indicate that pre-service teachers were knowledgeable about the in-class applications and that they were preparing themselves for these processes. Choosing SMTs for revision purposes imply that pre-service teachers were aware of the effectiveness of the course when using different activities with different methods.

There was no study examining the reasons for pre-service primary school teachers' determining SMT in the literature. However, the results of this study are consistent with findings of a study (Apaydın and Kandemir, 2018) conducted with primary school teachers in terms of some reasons about why they choose that objective such as being suitable for the objective and subject, providing permanent learning, making the course enjoyable, and contributing the students' metacognitive skills. This shows that both teachers and preservice teachers are able to put forward the same reasons in instructional processes.

As a result of this study, it is thought that conducting the theoretical and practical courses, especially the teaching courses, in a qualified manner, may be effective in increasing the self-efficacy of the pre-service teachers in science teaching. For this reason, it is recommended to give more importance to these courses in teacher education of pre-service primary school teachers. In these courses, it is recommended that faculty members actively involve pre-service teachers in the teaching process, especially while determining methodtechnique and strategy.

\section{REFERENCES}

Akbaş, A., \& Çelikkaleli, Ö. (2006). Examination of pre-service science teacher self-efficacy beliefs according to gender, type of education and university. Mersin University Journal of the Faculty of Education, 2(1), 98-110.

Apaydın, Z., \& Kandemir, M.A. (2018). Primary teacher opinions about teaching methods and techniques and evaluation tools and techniques used in science course. Dicle University Journal of Ziya Gokalp
Education Faculty, 33, 70-78.

Aston, P.T. (1984). Teacher efficacy: A motivational paradigm for effective teacher education. Journal of Teacher Education, 35(5), 28-32.

Avc1, A. (2008). The Relationship between Pre-service Elementary Teachers' Perception of Science Teachers and their Science Teaching Self-efficacy Beliefs through their Self-Drawings. (Unpublished Master Thesis. Ege University, Institute of Social Sciences, İzmir).

Balbağ, M.Z., \& Karaer, G. (2017). The problems of primary school teacher faced in the science teaching process. Trakya University, Journal of Education Faculty, 8(1), 28-46.

Bandura, A. (1986). Social Foundations of thought and Action: A Social Cognitive Theory. Englewood Cliffs, New Jersey: Prentice-Hall.

Bandura, A. (1997) Self-Efficacy: The Exercise of Control. New York: WH Freeman and Company.

Bardak, Ş., \& Karamustafaoğlu, O. (2016). Investigation about using strategies, methods and techniques of science teachers based on pedagogical content knowledge. Amasya Education Journal, 5(2), 567-605.

Bayraktar, S. (2011). Turkish preservice primary school teachers' science teaching efficacy beliefs and attitudes toward science: The effect of a primary teacher education program. School Science and Mathematics, 111(3), 83-92.

Bergman, D.J., \& Morphew, J. (2015). Effects of a science content course on elementary preservice teachers' self-efficacy of teaching. Science Journal of College Science Teaching, 44(3), 73-81.

Büyüköztürk, Ş., Kılıç Çakmak, E., Akgün, Ö.E., Karadeniz, Ş., \& Demirel, F. (2016). Scientific Research Methods. $20^{\text {th }}$ ed. Ankara: Pegem Publishing.

Cohen, J. (1988). Statistical Power Analysis for the Behavioral Sciences. $2^{\text {nd }}$ ed. Hillsdale, NJ: Erlbaum.

Çolak, İ., Yorulmaz, Y.I.., \& Altınkurt, Y. (2017). The validity and reliability study of teacher self-efficacy beliefs scale. Muğla Sitkı Koçman University Journal of Education, 4(1), 20-32.

Çorapçıgil, A., Hayal, M.A., \& Aydın, E. (2016). A phenomenological perspective of candidate classroom teachers' self-efficacy beliefs for science teaching. Turkish Studies, 11(9), 209-226.

Flores, I.M. (2015). Developing preservice teachers' self-efficacy through field-based science teaching practice with elementary students. Research in Higher Education Journal, 27, 1-19.

Gibson, S., \& Dembo, M.H. (1984). Teacher efficacy: A construct validation. Journal of Educational Psychology, 76, 569-582.

Gökgül, S. (2013). Relation between Science and Technology Selfefficacybeliefs and Attitudes Toward Science and Technology of Students in Primary School Teaching Department (Abant Izzet Baysal University). (Unpublished Master's Thesis. Bolu: Abant İzzet Baysal University Institute of Education Sciences.

Gunning, A.M., \& Mensah, F.M. (2011). Preservice elementary teachers' development of self-efficacy and confidence to teach science: A case study. Journal of Science Teacher Education, 22(2), 171-185.

Hazır-Bıkmaz, F. (2004). The Validity and Reliability Study of the Selfefficacy Belief Scale in Science Teaching of Primary School Teachers. Available from: https://www.dhgm.meb.gov.tr/yayimlar/dergiler/Milli_ Egitim Dergisi/161/bikmaz.htm. [Last accessed on 2019 Dec 21].

Hechter, R.P. (2011). Changes in preservice elementary teachers' personal science teaching efficacy and science teaching objective expectancies: The influence of context. Journal of Science Teacher Education, 22(2), 187-202.

Henson, R.K. (2001). Teacher Self-efficacy: Substantive Implications and Measurement Dilemmas. Available from: https://www.files.eric.ed.gov/ fulltext/ED452208.pdf. [Last accessed on 2019 Jul 07].

Huyugüzel-Çavaş, P., \& Kesercioğlu, T. (2008). Investigation of elementary teachers' competencies in teaching science and technology. Ege Journal of Education, 9(1), 75-94.

Kazempour, M. (2014). I can't teach science! A case study of an elementary pre-service teacher's intersection of science experiences, beliefs, attitude, and self-efficacy. International Journal of Environmental and Science Education, 9(1), 77-96.

Kazempour, M., \& Sadler, T.D. (2015). Pre-service teachers' science beliefs, attitudes, and self-efficacy: A multi-case study. Teaching Education, 26(3), 247-271. 
Klausmeier, H.S., \& Allen, P.S. (1978). Cognitive Development of Children and Youth a Longitudinal Study. New York: Academic Press.

Knaggs, C.M., \& Sondergeld, T.A. (2015). Science as a learner and as a teacher: Measuring science self-efficacy of elementary preservice teachers. School Science and Mathematics, 115(3), 117-128.

Koray, Ö. (2003). The Influence of Science Education Based on Creative Thinking on Learning Products. Unpublished Dissertation. Ankara: Gazi University, Institute of Education Sciences.

Meriç, G., \& Ersoy, E. (2007). The perceptions of the fourth class students of classroom teachers education program at science instruction related to the proficiency levels. Mersin University Journal of the Faculty of Education, 3(1), 51-62.

MoNe. (2018). Science Course Curriculum (Grades 3, 4, 5, 6, 7 and 8). Ankara, Turkey: Head Council of Education and Morality.

Morrell, P.D., \& Carroll, J.B. (2003). An extended examination of preservice elementary teachers' science teaching self-efficacy. School Science and Mathematics, 103(5), 246-251.

Özkan, Ö., Tekkaya, C., \& Cakıroğlu, J. (2004). Science Teachers' Understanding of Science Concepts, Attitude towards Science Teaching and Self-Efficacy Beliefs. $5^{\text {th }}$ National Science and Mathematics Education Congress Proceeding. p1300-1304.

Pajares, F. (1996). Self-efficacy beliefs in academic settings. Review of Educational Research, 66, 543-578.

Patton, M.Q. (2002). Two decades of developments in qualitative inquiry: A personal, experiential perspective. Qualitative Social Work, 1(3), 261-283.

Plourde, L.A. (2001). The Genesis of Science Teaching in the Elementary
School: The Influence of Student Teaching. Available from: http:// www.ed.psu.edu/c1/2001 aets/s-1-08-plourde.rtf. [Last accessed on 2017 Dec 07].

Riggs, I.M., \& Enochs, L.G. (1990). Toward the development of an elementary teacher's science teaching efficacy belief instrument Science Education, 74(6), 625-637.

Serin, M.K., \& Bayraktar, S. (2015). An examination of candidate classroom teachers' science teaching efficacy beliefs according to locus of control. Kafkas University Journal of the Institute of Social Sciences, 16, 51-71.

Sönmez, S. (2007). Preschool Teachers' Attitudes toward Science and Science Teaching. Unpublished Master Thesis. METU: The Graduate School of Naturel and Applied Sciences.

Taşkaya, S.M., \& Sürmeli, H. (2014). Evaluation of primary school teachers' teaching methods used in science and technology course. Gaziantep University Journal of Social Sciences, 13(1), 169-181.

Yangın, S., \& Dindar, H. (2007). The perceptions of teachers about the change on elementary school science and technology curriculum. Hacettepe University Journal of Education, 33(2), 240-252.

Yilmaz, M. (2014). The Relationship between Teacher Candidates'Learning Styles and their Conceptions about Teaching and Learning and their Science Teaching Efficacy Beliefs. Unpublished Master Thesis. Bolu: Abant İzzet Baysal University Institute of Education Sciences.

Yılmaz, M., \& Çimen, O. (2008). Self-efficiency belief levels of biology education of master students without thesis in biology education. Van Yüzüncü Yll University Journal of Education, 5(1), 20-29.

Yılmaz, M., Köseoğlu, P., Gerçek, C.A., \& Soran, H. (2004). Teacher selfefficacy belief. Journal of National Education, 58(5), 50-54. 